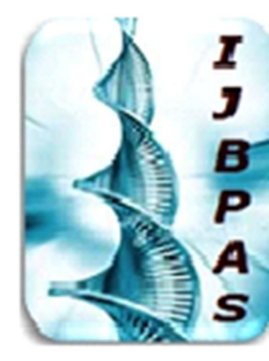

International Journal of Biology, Pharmacy and Allied Sciences (IJBPAS) 'A B Bridge Betuen Caboratory and QRendor'

www.ijbpas.com

\title{
EFFECT OF THE COVID-19 VACCINE ON MENSTRUAL IRREGULARITIES: A PROSPECTIVE STUDY IN WOMEN VACCINATED FROM A TERTIARY CARE CENTRE
}

\section{PENTELA G ${ }^{1}$, LADDAD MM² AND KSHIRSAGAR $\mathrm{N}^{3}$}

1: Post-Graduate Resident, Department of Obstetrics and Gynaecology, Krishna Institute of Medical Sciences, Karad, Maharastra, India

2: Associate Professor, Department of Obstetrics and Gynaecology, Krishna Institute of Medical Sciences, Karad, Maharastra, India

3: Professor, Department of Obstetrics and Gynaecology, Krishna Institute of Medical Sciences, Karad, Maharastra, India

*Corresponding Author: Dr. Greeshma Pentela: E Mail: greeshup95@gmail.com Received 12 ${ }^{\text {th }}$ July 2021; Revised 14 ${ }^{\text {th }}$ Aug. 2021; Accepted $27^{\text {th }}$ Oct. 2021; Available online $15^{\text {th }}$ Feb. 2022 https://doi.org/10.31032/IJBPAS/2022/11.2.1007

\section{ABSTRACT}

Purpose: Covid-19 vaccine was developed to prevent the infection caused by SARS CoV-2. However, the effects of the covid vaccine are not yet defined well. The main aim of this study was to find any association between the covid 19 vaccine and menstrual problems

\section{Methods:}

A prospective analysis was done over 115 women attending outpatient clinics who had received at least a single dose of the covid vaccine from March 2021 to May 2021. Follow up was made till 6 months using a preformed questionnaire and over the phone regarding the length of the menstrual cycle, duration of menses, any other associated factors during the post-vaccine status.

\section{Results:}

Most of the respondents received the Covidshield vaccine with maximum acceptance around 1825 years. There was not much significance when studying the difference in the menstrual pattern 
before the covid-19 pandemic and after covid 19 vaccination. However, $3.8 \%$ of cases had menorrhagia, 3.8\% prolonged menses, 3.8\% had severe pain in the abdomen, 11\% had nonspecific symptoms like fatigue, fever, weakness, numbness, during 1 st month of covid vaccination. When followed up further over 6 months, it has reduced to $2.7 \%$ cases of prolonged menses, $1.7 \%$ pain in the abdomen, no cases of menorrhagia and $4.7 \%$ had non-specific symptoms.

\section{Conclusion:}

The majority of the respondents of covid vaccine were compliant and had regular cycles like before. However, there are reported cases of heavy bleeding, prolonged menses, severe pain in the abdomen and other vaccine-related side effects which were of not much significance and the menstrual irregularities were mostly co-incidental.

\section{INTRODUCTION:}

Menstruation is a process where days and further follow up communications inflammation and the hemorrhagic event should be resolved quickly so that uterine function is restored and further infection and haemorrhage are prevented [1, 2]. Anything that disrupts the normal pathway of coagulation in the endometrium causes delay in the repair mechanisms leading to either sessation of menses early or prolonged menses. Currently, SARS-CoV-2 is prevalent in the world and many manufacturers have developed various vaccines to prevent it.

In new advent of the vaccine against $\mathrm{CoV}-2$, many women and girls started experiencing menstrual irregularities after vaccination which can be either the side effect of the vaccine or an co-incidental finding. Protocols created for vaccine trials do not monitor for major adverse effects for more than seven will not be inquiring about menstrual cycles or bleeding. To address this problem as either coincidence or a side effect of the vaccine, this observation was done. Public health care providers were unable to say whether there is any relation between covid vaccine administration and menstrual changes as there were no researches available on it, while few preferred saying it was mostly stress induced [3-6].

\section{Aims and objectives:}

To study any association between covid-19 vaccination and menstrual irregularities over a follow-up period of 6 months.

\section{METHODOLOGY:}

A prospective study was conducted on over 115 women who were vaccinated from March 2021 to May 2021 for the coronavirus 
and were followed up for their next 6 months from the date of vaccination. This study was conducted in the outpatient department services of obstetrics and gynaecology at Krishna Institute of Medical Sciences, Karad. All the girls and women belonging to the reproductive age group who were included in the study are not pregnant.

\section{Inclusion criteria:}

- Who were voluntarily willing to participate in the study

- Girls and women belonging to the reproductive age group (18-45years) and who were menstruating

- All participants who have received the first dose of vaccine from March 2021 to May 2021.

\section{Exclusion criteria:}

- Who was not ready to participate in the study

- Younger (<18years) and older age $(>45$ years $)$ group

- Who was not pregnant

Method: After meeting the inclusion and exclusion criteria,115 participants who were vaccinated were selected voluntarily by the random selection method from March 2021 to May 2021. They were followed up for 6 months using a questionnaire and over the phone and the following results were noted.

\section{RESULTS AND OBSERVATIONS:}

Analysis was done using descriptive analysis study and SPSS software and the following results were obtained. After data collection and segregation from March 2021 to May 2021, participants in our study $(\mathrm{N}=115)$ were 18-45 year group, the majority belonging to 18-24years(43.5\%) (Table 1).

All 115 cases are at least vaccinated for the first dose of coronavirus from March 2021 to May 2021. Respondents in this study were vaccinated with the following vaccines (Table 2).

Almost 90 cases $(78.3 \%)$ belong to upper socioeconomic status, $73.2 \%$ of cases were educated till graduation and 80\% (88) cases were settled in a good profession. 81.6\% (93) belong to the urban residence.

Out of 115 cases, $69.6 \%$ (80 cases) were not married and 92(82.1\%) have no other comorbidities, $8.9 \%$ (10 cases) have thyroid disease, PCOS $0.9 \%(1)$, hypertension $3.6 \%(4)$, asthma $1.8 \%(2)$

Out of 115 cases, 32 cases were infected with covid during their follow up accounting for $28.1 \%$, out of which 8 cases were hospitalized accounting for $8.9 \%, 23(22.8 \%)$ had mild symptoms, 4(5\%) were asymptomatic, $1(1 \%)$ required an oxygen mask (Table 3). 
Table 1: Age wise distribution

\begin{tabular}{|c|c|}
\hline Age group & Number of participants \\
\hline $18-24$ years & $53(43.5 \%)$ \\
\hline $24-29$ years & $34(29.8 \%)$ \\
\hline $30-34$ years & $6(5.3 \%)$ \\
\hline $35-39$ years & $7(6 \%)$ \\
\hline $40-45$ years & $15(13.2 \%)$ \\
\hline Total & $115(100 \%)$ \\
\hline
\end{tabular}

Table 2: Vaccine wise distribution of cases

\begin{tabular}{|c|c|}
\hline Vaccine & No of cases \\
\hline Covid shield & $95(83.3 \%)$ \\
\hline Covaxin & $16(13.9 \%)$ \\
\hline Others & $4(3.4 \%)$ \\
\hline Total & 115 \\
\hline
\end{tabular}

Table 3: Menstrual cycle changes in the study population

\begin{tabular}{|c|c|c|c|}
\hline Menstrual cycle changes & Before covid19 pandemic & $\begin{array}{c}\text { With covid 19-infection } \\
\text { (32cases) }\end{array}$ & After covid vaccination \\
\hline Regularity & Yes $(87.7 \%)$ & Yes $(62.7 \%)$ & Yes $(81.4 \%)$ \\
\hline Length of the cycle & Normal $(65.1 \%)$ & Yes $(61.3 \%)$ & Normal $(65.1 \%)$ \\
\hline Duration of menses & Normal (3-5days)70.8\% & Normal (67\%) & Normal $(65.1 \%)$ \\
\hline
\end{tabular}

Table 4: Menstrual cycle changes during the follow up status after covid vaccination

\begin{tabular}{|c|c|c|c|c|c|c|}
\hline $\begin{array}{c}\begin{array}{c}\text { Menstrual cycle } \\
\text { changes }\end{array} \\
\end{array}$ & $\begin{array}{c}\mathbf{1}^{\text {st }} \text { month after } \\
\text { vaccination }\end{array}$ & $\begin{array}{c}2^{\text {nd }} \text { month after } \\
\text { vaccination }\end{array}$ & $3^{\text {rd }}$ month & $4^{\text {th }}$ month & $5^{\text {th }}$ month & $6^{\text {th }}$ month \\
\hline No symptoms & $83.6 \%(92)$ & $\begin{array}{l}91.1 \% \\
(103) \\
\end{array}$ & $\begin{array}{c}91.09 \% \\
(102)\end{array}$ & $\begin{array}{c}107 \\
(93 \%)\end{array}$ & $\begin{array}{c}109 \\
(94.7 \%)\end{array}$ & $\begin{array}{c}105 \\
(91.3 \%) \\
\end{array}$ \\
\hline Prolonged menses & $2.7 \%(3)$ & $2(1.8 \%)$ & $3(2.7 \%)$ & $3(2.6 \%)$ & $3(2.6 \%)$ & $3(2.7 \%)$ \\
\hline Heavy bleeding & $4.5 \%(5)$ & $1(0.9 \%)$ & $1(0.9 \%)$ & $1(0.9 \%)$ & $\mathbf{0}$ & $\mathbf{0}$ \\
\hline $\begin{array}{c}\text { Severe pain in } \\
\text { abdomen }\end{array}$ & $3.6 \%(4)$ & $4(3.5 \%)$ & $3(2.7 \%)$ & $3(2.7 \%)$ & $2(1.8 \%)$ & $2(1.8 \%)$ \\
\hline $\begin{array}{c}\text { Others like non } \\
\text { specific symptoms }\end{array}$ & $9.5 \%(11)$ & $5(4.3 \%)$ & $6(5.2 \%)$ & $1(0.9 \%)$ & $1(0.9 \%)$ & $5(4.3 \%)$ \\
\hline
\end{tabular}

Table 5: Knowledge of study population on impact of covid 19 vaccine on menstrual cycle Relation between covid-19 vaccine and menstrual cycle

\begin{tabular}{|c|c|}
\hline Relation between covid-19 vaccine and menstrual cycle & $\mathbf{7 9 . 5 \% ( 8 9 )}$ \\
\hline Not Related & $\mathbf{8 \%}(\mathbf{9})$ \\
\hline Related & $\mathbf{1 7 ( 1 4 . 5 \% )}$ \\
\hline May be & \\
\hline
\end{tabular}

\section{DISCUSSION AND CONCLUSION:}

We studied the descriptive analysis of changes to the menstrual cycle in reproductive age group women after coronavirus vaccination. This study shows the post-vaccine experience towards the menstrual cycle irregularities for 6 months.
The majority of the study population belonging to the reproductive age group participated in the study were 18-24 years, majority of the respondents received covid shield vaccine (at least single dose), belonging to upper socioeconomic status, well educated, residing in urban areas. 
When studying the difference in the menstrual pattern before covid 19 pandemic and after covid 19 vaccination in the study population, there was not much significance. However few cases, 3.8\% had menorrhagia, $3.8 \%$ prolonged menses, $3.8 \%$ had severe pain in the abdomen, $11 \%$ had non-specific symptoms like fatigue, fever, weakness, numbness, during 1st month of covid vaccination.

When followed up further till 6 months, it has reduced to $2.7 \%$ cases of prolonged menses, $1.7 \%$ pain in the abdomen, no cases of menorrhagia and 4.7\% had non-specific symptoms.

With covid 19- infection in $27.8 \%$ (32 cases) of study, $12.5 \%$ (4cases) each had prolonged bleeding, heavy menses and severe pain in abdomen respectively.

When studied on the knowledge of the impact of the covid-19 vaccine on menstrual irregularities in the study population, $79.5 \%$ believed it is not related, $8 \%$ thought it is related, the remaining $14.5 \%$ believed it may be related.

\section{SUMMARY:}

This study showed that there are not many significant changes in the menstrual cycle irregularities due to the covid-19 vaccine. However, there are increased cases of heavy bleeding, prolonged menses associated with severe abdominal pain during the first month of post covid vaccination which gradually resolved when followed up over the next 6 months which were mostly coincidental rather than the side effects of the covid-19 vaccine.

\section{REFERENCES:}

[1] Critchley HO, Kelly RW, Baird DT, Brenner RM, Regulation of human endometrial function: mechanisms relevant to uterine bleeding, Reprod Biol Endocrinol, 4, 2006, S5.

[2] Spooner MK, Lenis YY, Watson R, Jaimes D, Patterson AL, The role of stem cells in uterine involution, Reproduction, 161, 2021, R61-R77.

[3] Cuda A, Is there a link between COVID vaccine and "funky" menstrual periods? Experts say it's too soon to know. Connecticut Post, 2021, (available at https://www.ctpost.com/news/coro navirus/article/Is-there-a-linkbetween-COVID-vaccine-and16112418.php).

[4] Lilly S, Can COVID-19 vaccine impact your menstrual cycle? Doctors address side-effects concerns. WTVR, 2021, (available 
at https://www.wtvr.com/news/corona

virus/covid-vaccine-menstrual-cycleimpacts).

[5] Stock N, Some people are reporting abnormal periods after a COVID-19 vaccine, U. of I. professor is looking for answers. chicagotribune.com, 2021, (available at https://www.chicagotribune.com/co $\underline{\text { ronavirus/vaccine/ct-vaccine-side- }}$ effects-period-menstruation20210420i4fy7a7tnnbchi654z3o64a $7 \mathrm{my}-$ story.html).

[6] Villarreal A, 'No data' linking Covid vaccines to menstrual changes, US experts say, The Guardian, 2021, (available

at https://www.theguardian.com/worl $\mathrm{d} / 2021 /$ apr/23/covid-vaccinesperiods-menstruation-changes-dataexperts). 